\title{
THE SECULAR TREND IN THE PREVALENCE OF OVERWEIGHT AND OBESITY IN THE POPULATION OF PRIMARY SCHOOL CHILDREN FROM LJUBLJANA (SLOVENIA) SEKULARNI TRENDI PREVALENCE PREKOMERNE PREHRANJENOSTI IN DEBELOSTI MED POPULACIJO LJUBLJANSKIH OSNOVNOŠOLCEV
} Marjeta Kovač ${ }^{1}$, Gregor Jurak ${ }^{1}$, Lijana Zaletel Kragelj², Bojan Leskošek ${ }^{1}$

Prispelo: 17. 6. 2013 - Sprejeto: 28. 1. 2014

\author{
Original scientific article \\ UDC 613.25-053.5(497.4 Ljubljana)
}

\begin{abstract}
Background: The prevalence of overweight and obesity among children has increased dramatically in recent decades. The survey examined overweight and obesity in the population of boys and girls from Ljubljana, the capital of Slovenia, aged seven through fourteen from 1991 to 2011.

Methods: An annually repeated cross-sectional study of data from the national SLOFIT monitoring system was used. The body mass index cut-off points of the International Obesity Task Force were used to identify the prevalence of overweight and obesity. Multinomial logistic regression was used for modelling the probability of overweight and obesity as a function of time (year of measurement), sex and age of subjects.

Results: In 1991-2011 period, the odds for overweight and obesity among primary school children ( $n=376,719)$ increased every year by 1.7\% (95\% Cl: 1.6-1.9) and 3.7\% (3.4-4\%) respectively. Boys have 1.17 (95\% Cl: 1.15-1.20) times higher odds of becoming overweight and 1.39 (95\% Cl: 1.35-1.44) times higher odds of becoming obese than girls. In comparison to the reference group (age of 14), the highest odds for overweight were found at the ages of nine and ten (1.39; 95\% Cl: 1.34-1.44), while for the obesity the highest odds were at the age of eight (2.01; 95\% Cl: 1.86-2.16). Conclusion: From 1991 to 2011, overweight and obesity clearly became more prevalent in children from Ljubljana. This trend has been more obvious among boys than girls. In comparison to 14-year-old boys and girls, the highest odds for excessive weight were found below the age of 10.
\end{abstract}

Key words: public health, childhood obesity, body mass index, primary school, sex, age

Izvirni znanstveni članek UDK 613.25-053.5(497.4 Ljubljana)

\section{Izvleček}

Izhodišča: $V$ razvitem svetu se zaznava izrazit porast prekomerne prehranjenosti in debelosti med otroki in mladostniki. $\checkmark$ raziskavi smo analizirali prekomerno prehranjenost in debelost med ljubljanskimi osnovnošolci, starimi od sedem do štirinajst let, v obdobju po osamosvojitvi Slovenije.

Metode: Uporabili smo podatke vsakoletnih meritev telesne višine in telesne mase iz nacionalne zbirke Športnovzgojni karton med letoma 1991 in 2011. V študijo je bila vključena populacija učencev ( $N=376.719)$, ki so $v$ opazovanem obdobju obiskovali ljubljanske osnovne šole, njihovi starši pa so pisno soglašali z meritvami. Iz dobljenih podatkov smo izračunali indekse telesne mase, za določitev prekomerne prehranjenosti pa smo uporabili merila Mednarodne delovne skupine za boj proti debelosti. Prevalenco prekomerne prehranjenosti in debelosti glede na spol in starost merjencev ter čas kot kovariato (leta merjenja) smo izračunali z multinominalno logistično regresijo.

Rezultati: Vsako leto se ne glede na spol merjencev obet za prekomerno prehranjenost poveča za 1,7\% $(95 \% \mathrm{Cl}$ : 1,6-1,9\%) in za debelost za 3,7\% (95\% Cl: 3,4-4\%). Med fanti je obet za prekomerno prehranjenost 1,17-krat (95\% Cl: 1,15-1,20) in za debelost 1,39-krat $(95 \%$ Cl: 1,35-1,44) večji kot med dekleti. Glede na štirinajstletnike je največji obet za prekomerno prehranjenost opazen med devet- in desetletniki $(1,39 ; 95 \%$ Cl: 1,34-1,44), za debelost pa med osemletniki (2,01; 95\% Cl: 1,86-2,16).

Zaključki: V obdobju med letoma 1991 in 2011 se je med ljubljanskimi osnovnošolci povečal delež prekomerno prehranjenih in debelih. Prevalenca prekomerne prehranjenosti in debelosti je večja pri fantih kot dekletih, v primerjavi $z$ učenci ob koncu šolanja pa je največja med osmim in desetim letom starosti.

Ključne besede: javno zdravje, otroška debelost, indeks telesne mase, osnovna šola, spol, starost

\footnotetext{
1 University of Ljubljana, Faculty of Sport, Gortanova 22, 1000 Ljubljana, Slovenia

2 University of Ljubljana, Medical Faculty, Department of Public Health, Zaloška 4, 1000 Ljubljana, Slovenia

Correspondence to: e-mail: marjeta.kovac@fsp.uni-lj.si
} 


\section{INTRODUCTION}

The extensive changes in people's lifestyles also influence the physical development of children and youth (1). Lack of movement and unsuitable eating habits result in overweight and obesity (OW\&OB) $(2,3)$ that are reaching epidemic proportions in the developed world (4-6).

The mechanism of obesity development is not fully understood. It has been confirmed that obesity occurs when energy intake exceeds energy expenditure, suggesting that a proper diet and physical activity are the key strategies for controlling the current epidemic of obesity (7). Genetic factors influence the susceptibility of a given child to an obesity-conducive environment. However, socio-economic status, level of education, lifestyle preferences and the cultural environment also seem to play major roles in the rising prevalence of obesity worldwide $(1,3,8)$.

The World Health Organisation has recognised obesity as a multifactorial disease with a complex aetiology, which holds many health consequences (9). Several reviews summarise the consequences, both shortand long-term, of childhood and adolescent obesity, including cardiovascular risk factors and coronary heart disease mortality, type 2 diabetes, non-alcoholic fatty liver disease, asthma, sleep-disordered breathing, systemic inflammation and orthopaedic problems (9-11). Furthermore, obesity also has social and psychological consequences: obesity is linked with low self-image, low self-confidence and depression $(11,12)$.

There is a wide variety of definitions of child obesity. No commonly accepted standard has yet emerged (13); although less sensitive than skin-fold thickness, body mass index (BMl; weight/height ${ }^{2}$ ) is widely used. A number of studies on the prevalence of OW\&OB in European children and adolescents in different years after 1990 showed that the prevalence was especially high in southern Europe and substantially lower in central and northern Europe (11, 14-16). There are differences in obesity prevalence between boys and girls, e.g. some studies conducted on British $(8,17)$, Irish (18), Spanish (19), Swedish (20) and Turkish (21) sub-populations showed higher prevalence among girls, while the data from the Health Behaviour in School-aged Children (HBSC) survey $(14,16)$ and studies conducted on Austrian (22), Italian (23) and Finish sub-populations (24) indicated the opposite trends. The reasons for this may include gender differences in food choices and dietary concerns (16). Gender patterns may indicate that environmental influences are more detrimental for boys: boys eat more fast food (25), while girls are more likely to pay attention to food as a way to influence health and to meet nutritional recommendations (16). Furthermore, parents are less likely to encourage boys to control their weight (16) and preventive interventions are less effective for boys (14).

In Slovenia, the prevalence of OW\&OB among children and adolescents has also increased dramatically in recent decades, especially in younger age groups $(26-30)$. It is important to follow secular trends of OW\&OB between age groups in childhood, as overweight and obese children have a greater risk of becoming overweight or obese adults $(27,31,32)$. Independent of genetic differences, environmental variables (geographic position, socio-economic level of family, educational level of parents, maternal employment, etc.) are extremely important predictors of obesity that operate in complex ways, both within and between countries $(8,28)$. Ljubljana, the capital of Slovenia, located in central geographic position of the country, has the highest rate of GDP per capita and the highest purchasing power standards; furthermore, the earnings of persons employed in Ljubljana are the highest in the country (33).

Therefore, the main purpose of the study was to examine the prevalence of OW\&OB among primary school children from Ljubljana, aged 7 to 14 . The aim of the study was to analyse twenty-year trends in the prevalence according to sex and age.

\section{METHODS}

\subsection{Participants}

The repeated studies consist of boys ( $n=194,415)$ and girls $(n=182,304)$ from Ljubljana primary schools who enrolled in the Slovenian physical fitness monitoring system (SLOFIT) (34) from 1991, the year of independence from the former Yugoslavia, until 2011. Only schools that were part of the Ljubljana municipality in 2011 were taken into consideration. Information on birth dates was obtained from school records. For data analysis, the age limits were set as follows: 7 years: $7.0-7.99$ years, 8 years: $8.0-8.99$ years, to 14 years: $14.0-14.99$ years.

Only healthy boys and girls who were not exempt from physical education (PE) for health reasons and whose parents had given their written consent to participate in the measurements were included. The number of subjects whose data of body height and body weight were included in the analysis is presented in Figure 1 and 2. Between 1991 and 2011 , slightly less than $95 \%$ of primary school boys and girls below the age of 15 were measured every year (30). 


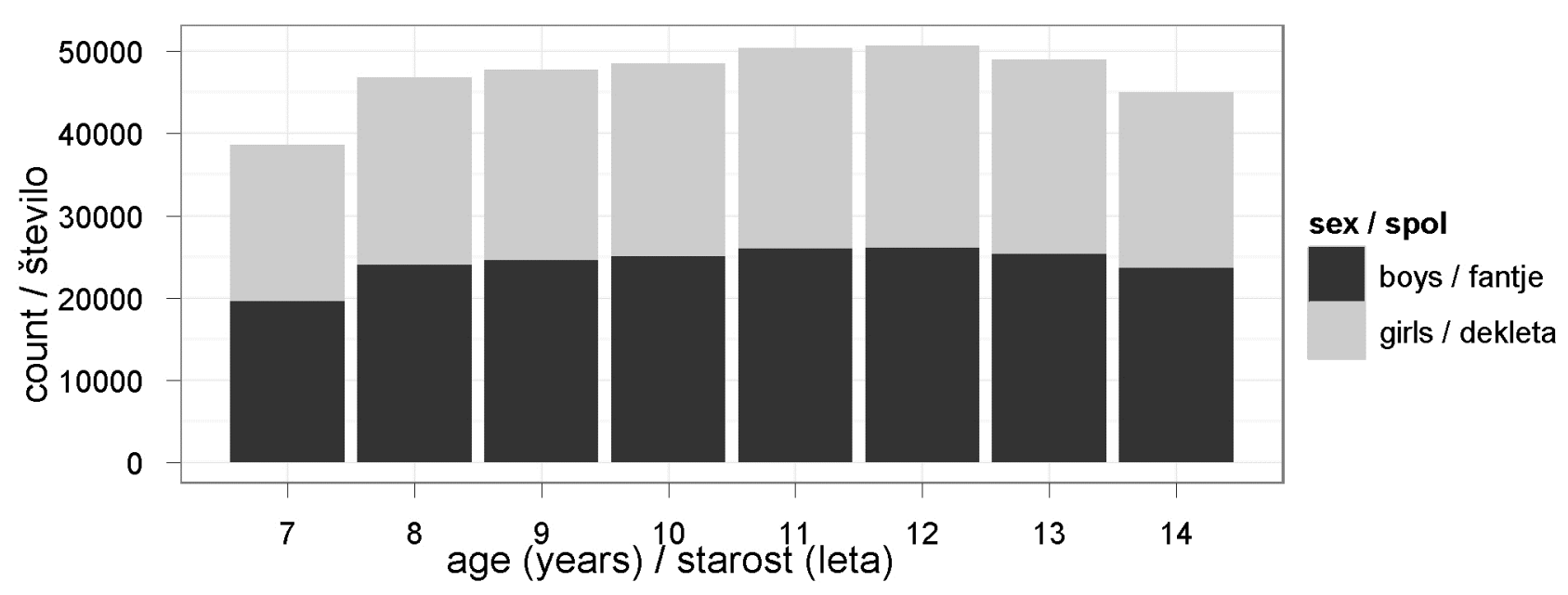

Figure 1. Structure of participants by age.

Slika 1 Struktura vzorca glede na starost.

The Slovenian school system has undergone a number of changes in recent years. The new nine-year primary education system was gradually implemented between school years 1999/2000 to 2007/2008. Some of the students that started with schooling earlier (before the age of 6 ) were not included in the sample; they were either not yet 7-years-old or they were older than 15-years-old before the April when measurements were held. Therefore, at the ages 7 and 14, a smaller proportion of students was included in the measurements.

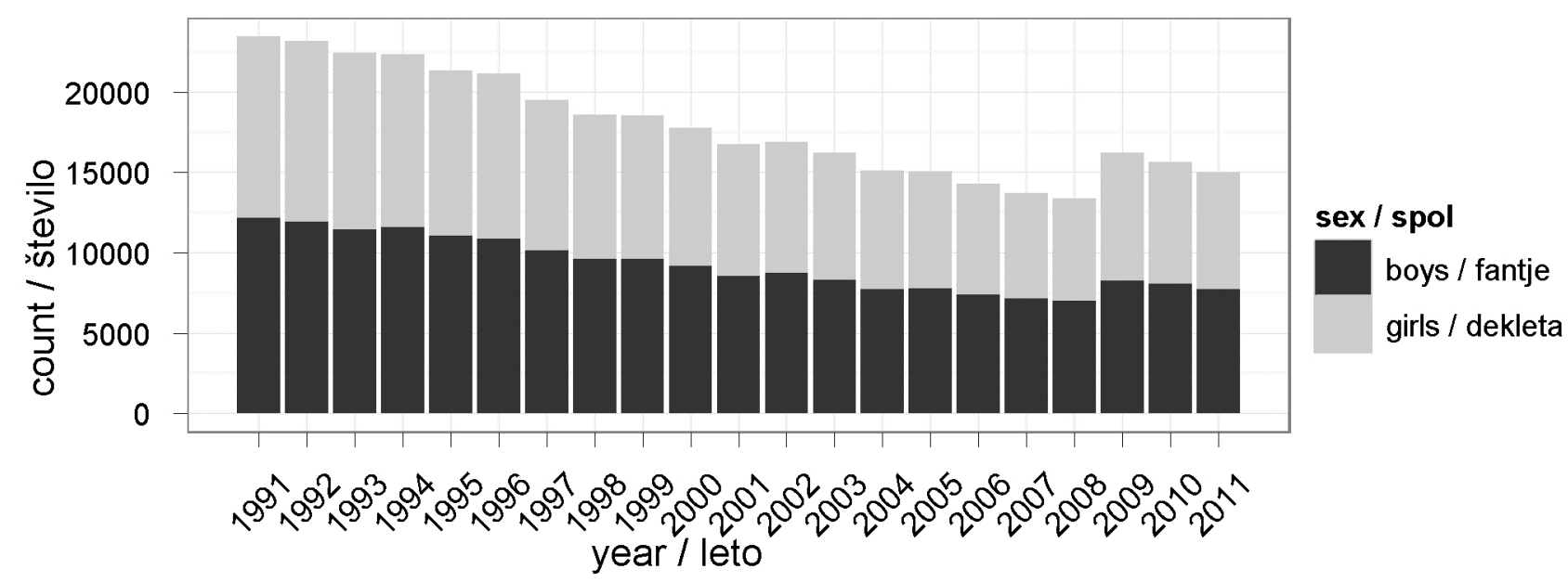

Figure 2. Structure of participants by year of observation.

Slika 2. Struktura vzorca glede na leta opazovanja.

As a result of the birth rate having strongly decreased from after the independence of Slovenia to 2003 (27) and not all children having been included in the nine-year basic education system at the same time, a smaller number of students was measured until 2008.

\subsection{Measurements}

The study was approved by the Human Research Ethics Committee of the Faculty of Sport, Ljubljana, Slovenia, and supported by the Ministry of Education, Science and Sport.
Measurements were held annually in April during PE classes in all Slovenian schools. All measurements of body height and body weight were conducted by trained PE teachers who completed a 30 -hour course in anthropometric measurement during their studies, according to the standard protocol. Subjects were barefoot in their shorts and T-shirts. Height was measured with stadiometers of various brands to the nearest $0.1 \mathrm{~cm}$ and weight with pre-calibrated portable scales of various brands to the nearest $0.1 \mathrm{~kg}$. The collected data were checked to detect coding errors. 


\subsection{Data analysis}

Data were analysed with the use of the SPSS 18.0 statistical package. OW\&OB were defined by International Obesity Task Force (IOTF) criteria (ageand sex-specific BMI cut-off points correspond to adults' cut-off points of $25 \mathrm{~kg} / \mathrm{m}^{2}$ for overweight and $30 \mathrm{~kg} / \mathrm{m}^{2}$ for obesity) $(5,35)$ and the prevalence was determined separately for age (7- to 14-years old), sex and the year of measurement (1991 to 2011).
Confidence intervals $(\mathrm{Cl})$ for the proportions were computed using the Collett formula (36). Multinomial logistic regression was performed to obtain adjusted odds ratios (AORs) and 95\% confidence intervals (95\% Cls), for modelling the probability of OW\&OB as a function of time (year of measurement as covariate) and sex and age of subjects as factors. In 1991, girls at age 14 were used as reference categories, separately for OW\&OB subsamples. The $p$-values $<0.05$ were considered statistically significant.

\section{RESULTS}

Table 1. Prevalence of overweight children in Ljubljana from 1991 to 2011 by sex (in \%).

Tabela 1. Prevalenca prekomerne prehranjenosti ljubljanskih otrok med 1991 in 2011 ločeno po spolu (v \%).

\begin{tabular}{|c|c|c|c|c|c|c|c|c|c|c|}
\hline \multirow{2}{*}{$\begin{array}{l}\text { Yearl } \\
\text { Leto }\end{array}$} & \multirow[b]{2}{*}{ Sex/ Spol } & \multicolumn{8}{|c|}{$\begin{array}{c}\text { Age (Years) } \\
\text { Starost (Leta) }\end{array}$} & \multirow{2}{*}{$\begin{array}{r}\text { Total } \\
\text { Skupaj }\end{array}$} \\
\hline & & 7 & 8 & 9 & 10 & 11 & 12 & 13 & 14 & \\
\hline \multirow[t]{2}{*}{1991} & Boys/ Fantje & 13.7 & 13.4 & 17.1 & 16.0 & 14.5 & 15.9 & 15.8 & 13.4 & 15.1 \\
\hline & Girls/ Dekleta & 13.5 & 15.6 & 16.2 & 14.3 & 14.7 & 12.3 & 11.9 & 9.2 & 13.5 \\
\hline \multirow[t]{2}{*}{1992} & Boys/ Fantje & 10.8 & 12.3 & 13.1 & 15.0 & 14.4 & 13.2 & 12.6 & 13.1 & 13.2 \\
\hline & Girls/ Dekleta & 12.2 & 11.9 & 13.0 & 13.1 & 12.1 & 11.0 & 10.5 & 7.6 & 11.4 \\
\hline \multirow[t]{2}{*}{1993} & Boys/ Fantje & 13.6 & 14.3 & 15.7 & 15.9 & 16.9 & 16.3 & 14.0 & 13.6 & 15.1 \\
\hline & Girls/ Dekleta & 14.8 & 14.6 & 14.1 & 14.6 & 13.4 & 12.3 & 10.3 & 8.8 & 12.7 \\
\hline \multirow[t]{2}{*}{1994} & Boys/ Fantje & 11.9 & 14.2 & 15.2 & 17.1 & 16.4 & 16.2 & 15.5 & 13.8 & 15.2 \\
\hline & Girls/ Dekleta & 15.3 & 16.2 & 14.8 & 14.0 & 14.3 & 13.1 & 10.8 & 8.2 & 13.2 \\
\hline \multirow[t]{2}{*}{1995} & Boys/ Fantje & 15.1 & 15.9 & 14.4 & 16.6 & 15.6 & 17.3 & 15.0 & 14.1 & 15.5 \\
\hline & Girls/ Dekleta & 15.8 & 15.4 & 16.2 & 15.4 & 14.0 & 12.1 & 12.4 & 8.6 & 13.7 \\
\hline \multirow[t]{2}{*}{1996} & Boys/ Fantje & 10.4 & 15.1 & 15.9 & 15.2 & 15.9 & 17.1 & 15.5 & 15.6 & 15.3 \\
\hline & Girls/ Dekleta & 14.2 & 15.0 & 16.5 & 15.9 & 14.7 & 13.6 & 12.3 & 10.5 & 14.1 \\
\hline \multirow[t]{2}{*}{1997} & Boys/ Fantje & 13.5 & 13.9 & 15.8 & 15.0 & 16.2 & 15.5 & 15.2 & 13.9 & 15.0 \\
\hline & Girls/ Dekleta & 14.6 & 17.1 & 15.7 & 16.2 & 14.2 & 13.2 & 10.5 & 9.2 & 13.9 \\
\hline \multirow[t]{2}{*}{1998} & Boys/ Fantje & 13.7 & 14.9 & 14.3 & 16.8 & 17.9 & 16.5 & 15.3 & 15.5 & 15.7 \\
\hline & Girls/ Dekleta & 15.3 & 16.1 & 16.4 & 15.0 & 15.7 & 13.6 & 12.9 & 9.5 & 14.4 \\
\hline \multirow[t]{2}{*}{1999} & Boys/ Fantje & 11.6 & 16.4 & 17.0 & 16.6 & 17.5 & 17.0 & 15.2 & 13.4 & 15.8 \\
\hline & Girls/ Dekleta & 17.5 & 16.9 & 16.8 & 17.2 & 14.2 & 14.6 & 12.2 & 9.6 & 14.8 \\
\hline \multirow[t]{2}{*}{2000} & Boys/ Fantje & 13.8 & 16.2 & 19.6 & 19.3 & 16.8 & 18.4 & 17.2 & 15.6 & 17.3 \\
\hline & Girls/ Dekleta & 14.5 & 17.1 & 18.6 & 17.9 & 16.4 & 16.0 & 12.4 & 9.5 & 15.4 \\
\hline \multirow[t]{2}{*}{2001} & Boys/ Fantje & 14.7 & 16.6 & 17.1 & 20.5 & 18.7 & 17.9 & 18.0 & 16.8 & 17.7 \\
\hline & Girls/ Dekleta & 18.1 & 15.9 & 17.4 & 19.0 & 17.1 & 16.8 & 11.4 & 9.1 & 15.5 \\
\hline 2002 & Boys/ Fantje & 12.8 & 15.6 & 16.9 & 15.4 & 20.8 & 18.4 & 16.7 & 16.7 & 16.8 \\
\hline
\end{tabular}




\begin{tabular}{|l|l|r|r|r|r|r|r|r|r|r|}
\hline & Girls/ Dekleta & 15.9 & 18.3 & 17.6 & 15.1 & 16.7 & 15.4 & 12.5 & 9.1 & 15.1 \\
\hline $\mathbf{2 0 0 3}$ & Boys/ Fantje & 14.0 & 14.1 & 17.0 & 17.9 & 18.1 & 19.5 & 16.6 & 13.0 & 16.4 \\
\hline & Girls/ Dekleta & 13.7 & 16.8 & 17.3 & 18.4 & 14.5 & 15.6 & 12.6 & 12.6 & 15.2 \\
\hline $\mathbf{2 0 0 4}$ & Boys/ Fantje & 13.8 & 17.2 & 18.1 & 18.6 & 19.0 & 18.9 & 18.7 & 17.2 & 17.7 \\
\hline & Girls/ Dekleta & 13.0 & 15.7 & 19.4 & 17.0 & 17.4 & 13.8 & 12.3 & 9.7 & 14.8 \\
\hline $\mathbf{2 0 0 5}$ & Boys/ Fantje & 13.0 & 15.6 & 20.0 & 17.5 & 19.7 & 21.0 & 18.9 & 19.0 & 18.1 \\
\hline & Girls/ Dekleta & 13.6 & 15.1 & 17.6 & 16.9 & 16.5 & 16.5 & 10.4 & 12.8 & 15.0 \\
\hline $\mathbf{2 0 0 6}$ & Boys/ Fantje & $\mathbf{1 2 . 1}$ & $\mathbf{1 6 . 5}$ & $\mathbf{1 9 . 3}$ & $\mathbf{2 1 . 5}$ & $\mathbf{1 8 . 8}$ & $\mathbf{1 8 . 8}$ & $\mathbf{1 9 . 3}$ & $\mathbf{1 9 . 1}$ & $\mathbf{1 8 . 0}$ \\
\hline & Girls/ Dekleta & $\mathbf{1 4 . 6}$ & $\mathbf{1 6 . 5}$ & $\mathbf{1 7 . 1}$ & $\mathbf{1 7 . 9}$ & $\mathbf{1 8 . 2}$ & $\mathbf{1 5 . 4}$ & $\mathbf{1 3 . 9}$ & $\mathbf{1 0 . 5}$ & $\mathbf{1 6 . 1}$ \\
\hline $\mathbf{2 0 0 7}$ & Boys/ Fantje & 11.8 & 15.6 & 18.2 & 18.6 & 23.2 & 20.3 & 19.9 & 16.5 & 18.0 \\
\hline & Girls/ Dekleta & 16.5 & 19.0 & 18.0 & 17.3 & 16.1 & 15.8 & 14.3 & 11.6 & 16.1 \\
\hline $\mathbf{2 0 0 8}$ & Boys/ Fantje & 14.4 & 15.4 & 18.6 & 18.8 & 19.9 & 20.7 & 19.3 & 15.1 & 17.7 \\
\hline & Girls/ Dekleta & 12.5 & 18.1 & 18.1 & 16.2 & 14.5 & 16.2 & 13.3 & 10.7 & 15.0 \\
\hline $\mathbf{2 0 0 9}$ & Boys/ Fantje & 13.3 & 17.7 & 16.6 & 18.8 & 21.0 & 20.6 & 20.1 & 18.1 & 18.3 \\
\hline & Girls/ Dekleta & 14.7 & 15.7 & 19.0 & 18.4 & 16.1 & 14.3 & 14.2 & 13.5 & 15.7 \\
\hline $\mathbf{2 0 1 0}$ & Boys/ Fantje & 12.9 & 16.9 & 18.9 & 19.0 & 19.7 & 20.8 & 19.5 & 21.2 & 18.7 \\
\hline & Girls/ Dekleta & 14.7 & 17.2 & 17.4 & 18.1 & 17.7 & 16.0 & 13.6 & 13.5 & 16.0 \\
\hline $\mathbf{2 0 1 1}$ & Boys/ Fantje & $\mathbf{1 2 . 1}$ & $\mathbf{1 6 . 0}$ & $\mathbf{1 9 . 0}$ & $\mathbf{1 8 . 4}$ & $\mathbf{1 9 . 6}$ & $\mathbf{1 9 . 8}$ & $\mathbf{1 8 . 5}$ & $\mathbf{1 8 . 3}$ & $\mathbf{1 7 . 8}$ \\
\hline & Girls/ Dekleta & $\mathbf{1 2 . 1}$ & $\mathbf{1 6 . 9}$ & $\mathbf{1 9 . 2}$ & $\mathbf{1 6 . 6}$ & $\mathbf{1 8 . 2}$ & $\mathbf{1 7 . 7}$ & $\mathbf{1 4 . 9}$ & $\mathbf{1 1 . 6}$ & $\mathbf{1 5 . 9}$ \\
\hline
\end{tabular}

Table 2. Prevalence of obese children in Ljubljana from 1991 to 2011 by sex (in \%).

Tabela 2. Prevalenca debelosti ljubljanskih otrok med 1991 in 2011 ločeno po spolu (v \%).

\begin{tabular}{|c|c|c|c|c|c|c|c|c|c|c|}
\hline \multirow{2}{*}{$\begin{array}{l}\text { Yearl } \\
\text { Leto }\end{array}$} & \multirow[b]{2}{*}{ Sex/Spol } & \multicolumn{8}{|c|}{$\begin{array}{c}\text { Age (Years) } \\
\text { Starost (Leta) }\end{array}$} & \multirow{2}{*}{$\begin{array}{r}\text { Total } \\
\text { Skupaj }\end{array}$} \\
\hline & & 7 & 8 & 9 & 10 & 11 & 12 & 13 & 14 & \\
\hline \multirow[t]{2}{*}{1991} & Boys/ Fantje & 3.2 & 3.9 & 2.8 & 3.5 & 3.0 & 3.0 & 2.2 & 1.5 & 2.9 \\
\hline & Girls/ Dekleta & 3.9 & 4.0 & 2.6 & 2.7 & 1.3 & 1.7 & 1.1 & 0.6 & 2.2 \\
\hline \multirow[t]{2}{*}{1992} & Boys/ Fantje & 2.9 & 3.1 & 2.6 & 1.9 & 2.8 & 2.2 & 1.9 & 1.7 & 2.3 \\
\hline & Girls/ Dekleta & 3.8 & 3.3 & 2.2 & 2.1 & 1.9 & 1.0 & 0.9 & 0.5 & 1.9 \\
\hline \multirow[t]{2}{*}{1993} & Boys/ Fantje & 4.2 & 3.8 & 2.8 & 3.6 & 2.2 & 2.3 & 2.7 & 1.8 & 2.8 \\
\hline & Girls/ Dekleta & 4.9 & 3.9 & 3.3 & 2.4 & 2.2 & 2.2 & 1.6 & 1.0 & 2.6 \\
\hline \multirow[t]{2}{*}{1994} & Boys/ Fantje & 4.8 & 3.7 & 3.4 & 3.3 & 3.3 & 2.9 & 2.6 & 2.1 & 3.2 \\
\hline & Girls/ Dekleta & 3.6 & 2.7 & 3.2 & 2.9 & 2.2 & 1.5 & 2.0 & 1.7 & 2.4 \\
\hline \multirow[t]{2}{*}{1995} & Boys/ Fantje & 4.4 & 4.1 & 4.3 & 2.8 & 3.5 & 2.4 & 2.4 & 3.2 & 3.3 \\
\hline & Girls/ Dekleta & 4.9 & 3.5 & 3.7 & 2.7 & 2.6 & 1.7 & 1.2 & 1.7 & 2.7 \\
\hline
\end{tabular}




\begin{tabular}{|c|c|c|c|c|c|c|c|c|c|c|}
\hline 1996 & Boys/ Fantje & 3.2 & 4.7 & 4.7 & 4.2 & 3.8 & 2.8 & 2.8 & 3.2 & 3.7 \\
\hline & Girls/ Dekleta & 5.2 & 4.7 & 3.7 & 3.4 & 3.1 & 2.9 & 2.3 & 1.7 & 3.3 \\
\hline \multirow[t]{2}{*}{1997} & Boys/ Fantje & 4.9 & 3.6 & 4.8 & 4.3 & 3.4 & 2.9 & 2.2 & 1.9 & 3.5 \\
\hline & Girls/ Dekleta & 4.1 & 4.2 & 3.9 & 3.1 & 2.7 & 2.6 & 2.0 & 0.7 & 2.9 \\
\hline \multirow[t]{2}{*}{1998} & Boys/ Fantje & 5.7 & 6.1 & 3.7 & 4.6 & 4.1 & 4.0 & 3.1 & 2.1 & 4.1 \\
\hline & Girls/ Dekleta & 5.3 & 4.7 & 4.8 & 3.5 & 2.7 & 2.9 & 1.7 & 2.5 & 3.5 \\
\hline \multirow[t]{2}{*}{1999} & Boys/ Fantje & 4.0 & 5.3 & 4.7 & 3.7 & 4.6 & 4.7 & 3.6 & 2.4 & 4.2 \\
\hline & Girls/ Dekleta & 5.1 & 5.2 & 4.2 & 3.8 & 2.8 & 1.9 & 2.0 & 1.7 & 3.2 \\
\hline \multirow[t]{2}{*}{2000} & Boys/ Fantje & 5.8 & 3.4 & 3.9 & 4.8 & 4.0 & 4.2 & 3.3 & 3.5 & 4.0 \\
\hline & Girls/ Dekleta & 5.9 & 4.4 & 5.3 & 3.4 & 2.3 & 1.8 & 1.6 & 1.3 & 3.2 \\
\hline \multirow[t]{2}{*}{2001} & Boys/ Fantje & 5.2 & 5.7 & 4.4 & 3.2 & 5.2 & 3.0 & 3.2 & 3.3 & 4.1 \\
\hline & Girls/ Dekleta & 5.2 & 4.7 & 3.8 & 4.0 & 2.7 & 2.2 & 2.0 & 1.2 & 3.1 \\
\hline \multirow[t]{2}{*}{2002} & Boys/ Fantje & 4.7 & 4.8 & 4.8 & 4.0 & 3.6 & 4.3 & 2.7 & 3.0 & 3.9 \\
\hline & Girls/ Dekleta & 4.2 & 4.6 & 3.4 & 2.8 & 3.8 & 1.9 & 2.0 & 2.1 & 3.1 \\
\hline \multirow[t]{2}{*}{2003} & Boys/ Fantje & 4.3 & 5.1 & 4.6 & 3.3 & 3.3 & 3.8 & 3.5 & 2.6 & 3.8 \\
\hline & Girls/ Dekleta & 4.6 & 4.3 & 4.2 & 2.7 & 1.9 & 2.4 & 1.7 & 1.0 & 2.8 \\
\hline \multirow[t]{2}{*}{2004} & Boys/ Fantje & 4.5 & 5.0 & 3.5 & 5.3 & 4.8 & 3.6 & 4.4 & 4.5 & 4.5 \\
\hline & Girls/ Dekleta & 3.2 & 4.7 & 3.7 & 3.8 & 2.8 & 2.4 & 1.8 & 1.4 & 3.0 \\
\hline \multirow[t]{2}{*}{2005} & Boys/ Fantje & 4.9 & 4.4 & 5.3 & 5.2 & 4.9 & 5.1 & 4.2 & 3.6 & 4.7 \\
\hline & Girls/ Dekleta & 3.6 & 4.0 & 3.6 & 4.0 & 3.3 & 2.6 & 2.0 & 1.4 & 3.1 \\
\hline \multirow[t]{2}{*}{2006} & Boys/ Fantje & 4.8 & 5.8 & 5.0 & 5.6 & 5.4 & 6.2 & 5.0 & 4.2 & 5.4 \\
\hline & Girls/ Dekleta & 7.0 & 4.4 & 4.8 & 3.9 & 3.5 & 3.3 & 2.7 & 2.2 & 4.1 \\
\hline \multirow[t]{2}{*}{2007} & Boys/ Fantje & 5.8 & 5.3 & 5.5 & 4.9 & 5.0 & 3.9 & 5.3 & 5.4 & 5.1 \\
\hline & Girls/ Dekleta & 3.4 & 5.4 & 3.0 & 4.6 & 3.7 & 2.9 & 2.6 & 2.3 & 3.5 \\
\hline \multirow[t]{2}{*}{2008} & Boys/ Fantje & 5.8 & 6.0 & 6.0 & 5.5 & 4.9 & 6.9 & 4.4 & 5.9 & 5.7 \\
\hline & Girls/ Dekleta & 4.8 & 4.6 & 6.2 & 2.7 & 3.6 & 2.3 & 2.6 & 2.2 & 3.7 \\
\hline \multirow[t]{2}{*}{2009} & Boys/ Fantje & 5.1 & 6.1 & 5.7 & 5.6 & 5.4 & 6.1 & 5.7 & 5.0 & 5.6 \\
\hline & Girls/ Dekleta & 4.3 & 5.0 & 4.2 & 4.0 & 3.0 & 3.5 & 2.9 & 2.1 & 3.6 \\
\hline \multirow[t]{2}{*}{2010} & Boys/ Fantje & 5.1 & 7.2 & 6.2 & 6.6 & 6.4 & 5.6 & 6.4 & 5.3 & 6.1 \\
\hline & Girls/ Dekleta & 4.4 & 5.0 & 4.3 & 4.0 & 5.2 & 2.7 & 3.3 & 2.7 & 3.9 \\
\hline \multirow[t]{2}{*}{2011} & Boys/ Fantje & 4.8 & 5.4 & 6.3 & 6.4 & 5.8 & 5.7 & 6.9 & 5.2 & 5.8 \\
\hline & Girls/ Dekleta & 4.1 & 4.8 & 4.1 & 3.9 & 3.8 & 3.6 & 2.5 & 2.6 & 3.7 \\
\hline
\end{tabular}


The prevalence of OW\&OB (\%) between 1991 and 2011 when the entire sample $(n=376,719)$ is considered, irrespective of the boys' and girls' ages, is presented in Tables 1 and 2. The prevalence of OW\&OB showed some small fluctuations but with significant trends of increasing. The proportion of overweight boys grew from $15.1 \%(n=1,839 ; 95 \% \mathrm{Cl}$ : $14.5-15.8)$ in 1991 to $17.8 \%(n=1,372 ; 95 \% \mathrm{Cl}: 16.9-18.6)$ in 2011 and obese boys from $2.9 \%(n=352 ; 95 \% \mathrm{Cl}$ : $2.6-3.2)$ to $5.8 \%(\mathrm{n}=450 ; 95 \% \mathrm{Cl}: 5.3-6.4)$. The proportion of overweight girls grew from $13.5 \%(\mathrm{n}=$ $1,528 ; 95 \% \mathrm{Cl}: 12.9-14.2)$ to $15.9 \%(n=1,156 ; 95 \%$
Cl: 15.1-16.7) and obese girls from 2.2\% $(n=246$; 95\% Cl: $1.9-2.5)$ to $3.7 \%(n=266 ; 95 \% \mathrm{Cl}: 3.2-4.1)$ respectively. In all observed years, the prevalence of OW\&OB was significantly higher among boys than among girls.

In recent years, it has been observed that the 9- to 13-year age group represents the largest proportion of OW\&OB boys (between $23 \%$ and $26 \%$ ), whereas among girls the highest proportions of OW\&OB are observed among the 8- to 12-year age group (between $20 \%$ and $23 \%$ ). The lowest percentage of OW\&OB is observed among 7-year-old boys and 14-year-old girls.

Table 3. Adjusted odds ratios (AOR; with 95\% Cl) in multinomial regression model for the prediction of overweight and obesity.

Tabela 3. Prilagojena razmerja obetov (AOR; s 95\% intervalom zaupanja) in multinominalni regresijski model za napovedovanje prekomerne prehranjenosti in debelosti.

\begin{tabular}{|l|c|c|c|c|c|}
\hline $\begin{array}{l}\text { Observed categoryl } \\
\text { opazovani } \\
\text { dejavniki }\end{array}$ & $\begin{array}{c}\text { Reference categoryl } \\
\text { referenčne } \\
\text { kategorije }\end{array}$ & $\begin{array}{c}\text { AOR }(95 \% \text { Cl) - } \\
\text { overweight/ } \\
\text { prekomerna prehranjenost }\end{array}$ & $\mathbf{p}$ & $\begin{array}{c}\text { AOR (95\% Cl) - obese/ } \\
\text { debelost }\end{array}$ & $\mathbf{p}$ \\
\hline $\begin{array}{l}\text { Year of survey/ } \\
\text { Leto meritev: }\end{array}$ & 1991 & $1.017(1.016-1.019)$ & $<0.001$ & $1.037(1.034-1.04)$ & $<0.001$ \\
\hline 2011 & & & & & \\
\hline Sex/Spol: & Girls/Dekleta & $1.17(1.15-1.20)$ & $<0.001$ & $1.39(1.35-1.44)$ & $<0.001$ \\
\hline Boys/Fantje & & & & & \\
\hline Age/Starost: & 14 years/let & $1.09(1.05-1.14)$ & $<0.001$ & $1.92(1.78-2.07)$ & $<0.001$ \\
\hline 7 years/let & 14 years/let & $1.29(1.24-1.34)$ & $<0.001$ & $2.01(1.86-2.16)$ & $<0.001$ \\
\hline 8 years/let & 14 years/let & $1.39(1.34-1.44)$ & $<0.001$ & $1.84(1.70-1.98)$ & $<0.001$ \\
\hline 9 years/let & 14 years/let & $1.39(1.34-1.44)$ & $<0.001$ & $1.68(1.56-1.81)$ & $<0.001$ \\
\hline 10 years/let & 14 years/let & $1.36(1.31-1.41)$ & $<0.001$ & $1.53(1.42-1.66)$ & $<0.001$ \\
\hline 11 years/let & 14 years/let & $1.31(1.26-1.35)$ & $<0.001$ & $1.36(1.26-1.47)$ & $<0.001$ \\
\hline 12 years/let & 14 years/let & $1.15(1.11-1.19)$ & $<0.001$ & $1.18(1.09-1.28)$ & $<0.001$ \\
\hline 13 years/let & & & & & \\
\hline
\end{tabular}

The multinomial logistic regression model (Table 3) for the prediction of OW\&OB with the sex and age of subjects as factors and year of measurement as covariate was found to be highly significant $\left(X^{2}=289\right.$, $p<.001)$. In every year from 1991 to 2011 , the odds for OW\&OB increased by $1.7 \%(95 \% \mathrm{Cl}: 1.6-1.9)$ and $3.7 \%(95 \% \mathrm{Cl}: 3.4-4)$ respectively. Boys have 1.17 (95\% Cl: 1.15-1.20) times higher odds of becoming overweight and 1.39 (95\% Cl: 1.35-1.44) times higher odds of becoming obese than girls. In comparison to reference group (age of 14), the highest odds for being overweight was found at the ages of nine and ten (AOR=1.39; 95\% Cl: 1.34-1.44), while for obesity the highest odds were at the age of eight years (AOR=2.01; 95\% Cl: 1.86-2.16).

\section{DISCUSSION}

The main finding of our study is that during 1991-2011, OW\&OB became clearly more prevalent in children from Ljubljana with the only real exception at the beginning of the studied period, which is probably due to a significant migration of the population after the 
establishment of the new state of Slovenia in 1991 (37).

The increase in the proportion of OW\&OB children in developed countries is a result of the different ways young people spend their free time, characterised mainly by physical inactivity (2) and inappropriate diets marked by energy-rich food and unsuitable eating habits $(14,16,38)$. Furthermore, in Slovenia the volume of free-time physical activities gradually decreases with age (39-41) and the food intake pattern (skipping breakfast and drinking soft-drinks daily) deviates markedly from healthy eating patterns (16).

After 1990, the prevalence of OW\&OB children aged around 7 to 11 years (using the IOTF cut-off points) was especially high in southern Europe (Italy 36\%, Spain $34 \%$, Greece 31\%) and substantially lower in northern Europe (Netherlands 12\%, Denmark 15\%, Germany 16\%) (11). In the 2006 HBSC study (based on self-reporting), the prevalence of overweight among 11-, 13- and 15-year-olds was similar among Central, Eastern and Northern-European (10.3\% to $11.7 \%$ ) regions and much higher in the Southern-European region (14). The same patterns were seen also in the 2009/2010 HBSC study (16): the highest rates of OW\&OB among 11- and 13-year-olds were seen in North America (around 30\%) but prevalence was also high in Southern (Greek boys 26.3\% and girls 15.3\%; Portuguese boys $24.7 \%$ and girls $16 \%$; Italian boys $21.3 \%$ and girls 13\%) and some Eastern European countries (Polish boys $20.7 \%$ and girls $13.3 \%$ ). In the PRO Children Survey, parents reported height and weight of children and BMI values were analysed using the US Centres of Disease Control and Prevention and the IOTF reference populations (15). They found that in 2003 the prevalence of OW\&OB among 11-years olds between the nine European countries varied from $8.6 \%$ to $30.6 \%$ and $5.9 \%$ to $26.5 \%$ respectively, depending on the reference population, with the lowest prevalence in Dutch girls and the highest in Portuguese boys. Obesity prevalence varied from 1.1\% (Dutch and Danish girls) to $10.7 \%$ (Portuguese boys) and from $0.3 \%$ (Dutch girls) to $6.2 \%$ (Portuguese boys) respectively. In 2009 , more 11- and 13-years old girls and boys from Ljubljana were overweight or obese in comparison with the Slovenian sub-sample in the $2009 / 2010$ HBSC study (11-yearold girls $19.1 \%$ vs. $16 \%$; 13 -year-old girls $17.1 \%$ vs. $13 \%$; 11 -year-old boys $26.4 \%$ vs. $22 \%$; 13 -year old boys $25.8 \%$ vs. $20 \%$ respectively) (16). The results of this study are not directly comparable with the results of the HBSC Studies $(14,16)$ and the PRO Children Survey (15), while self-reported weight and height could have resulted in some underreporting of (over)weight (42). Among Ljubljana's girls, the highest increase of OW\&OB rates was observed between 1991-1996 and
2001-2005, while among boys between 1996-2001 and 2006-2011. The reasons for these differences are unclear. Nevertheless, we can conclude that the prevalence of OW\&OB among Ljubljana's juvenile population, its secular trends and pattern of changes from childhood to early adolescence are lower to those in the USA (4, 16), Ireland (18) and countries from the southern European region (Portugal, Spain, Italy, Greece, Malta) $(11,15,16,43)$ and higher than in the northern (Denmark, Finland, Sweden) $(15,16,24$, 44 ) and central European region (Austria, Germany, Netherlands) $(15,16)$.

Moreover, in the twenty-year period, the increase of prevalence of OW\&OB among children from Ljubljana is lower in comparison with the Slovenian population (30). In 1991, more boys from Ljubljana were OW\&OB compared with the Slovenian population of the same ages (Ljubljana $18 \%$ vs. the rest of Slovenia $15.9 \%$ ), while in 2011 contrary data were observed (Ljubljana $23.6 \%$ vs. the rest of Slovenia $27.9 \%$ ). There were small differences among girls from Ljubljana and girls from the rest of Slovenia in 1991 (15.7\% vs. 15.5\%), while in 2011 the prevalence of OW\&OB is much higher among girls from the rest of Slovenia than among their counterparts from Ljubljana $(24.6 \%$ vs. $19.6 \%$ respectively). A possible explanation for the less prominent changes in BMI among Ljubljana's school population obviously lies in the changes in living habits, including more opportunities for physical activity and healthier nutrition. As the capital city, Ljubljana has the highest rate of GDP per capita (33) and the highest number of sport clubs (45); in the previous four years, between 60 and $70 \mathrm{PE}$ teachers have been employed in sport clubs and paid by the municipality to ensure free access to sport programmes for children and youth (45). Although we cannot infer causality from this study, our results may also indicate that changes in the environment have not similarly affected all age groups and the juvenile population living in different environments (urban, sub-urban and rural).

Between 2010 and 2011, the prevalence of OW\&OB in Ljubljana's population, especially among girls, may have reached a plateau, as in some other countries $(4,44,46)$.

In 7-year-old children, the secular trend was less prominent. In boys, the prevalence of OW\&OB showed no trend during the past 20 years $(16.9 \%)$ and among girls the prevalence was still decreased ( $17.4 \%$ vs. $16.2 \%$ respectively). Similar findings have been reported among pre-school children in the Czech Republic, France, the Netherlands and Sweden (47, 48). It may be that 7 -year-old children have retained their need for spontaneous physical activity and they do not spend so much time watching television and using other electronic devices (24). 
In recent years, the lowest percentage of OW\&OB is observed among 14-year-old girls. Girls have been become slimmer in adolescence, most probably as a result of attention to foods as a way to meet nutritional recommendations (16).

Obesity is rising at higher rates than overweight (odds $1.7 \%$ vs. $3.7 \%$ per year respectively), especially among boys. Interestingly, the physical activity level among primary school boys is still higher than among girls, but the level of their physical fitness has declined in previous decades, in comparison with girls (40). Moreover, the highest proportion of children with excessive weight is observed particularly in the period between the ages of 10 and 13 , when young people have the best conditions available for sports activities in schools (three hours of PE per week; PE is taught by specialised PE teachers in good working conditions with a smaller number of children in a group, etc.) and still show an interest in free-time sports participation in sports clubs (40). Although there is a close correlation between the amount of body fat and BMI (49), it is not possible to make an exact prediction of excessive weight on the basis of $\mathrm{BMI}$, because a higher BMI can be the result of a higher proportion of fat mass or muscle mass (50). It has been suggested that the reference values of the IOTF for a specific age group are not particularly suitable. This anomaly of the BMI distribution found on the studied population is also characteristic of other populations (51). For this reason, Starc and Strel (13) suggested that the nationally-specific BMI cut-off points, based on more recent data than international references, would be appropriate for defining underweight, overweight and obesity in Slovenian school-aged population.

The findings about differences between boys and girls in prevalence of OW\&OB as defined by BMI are generally inconsistent $(4,8,17-21,23,24)$ and may result from differences in biology (sex differences) or those assumed to be due to society or culture (gender differences), or a combination of the two (25, 52). However, more Ljubljana boys are overweight (from $13.2 \%$ to $18.7 \%$ vs. $11.4 \%$ to $16.1 \%$ ) and obese (from $2.2 \%$ to $6.1 \%$ vs. $1.9 \%$ to $4.1 \%$ ) than girls in all age groups in all observed years. Furthermore, a comparison with Škerlj's data (53) showed that between 1939 and 2011 the BMI among 11- to 19-year olds from Ljubljana increased on average by $32.6 \%$ among boys and $21.4 \%$, among girls respectively (12). Our results are similar to the data from the HBSC studies $(14,16)$ and previous studies from SLOFIT system data $(26,27,30)$, while Planinšec and Fošnarič (28) found no differences in the prevalence of OW\&OB among 6- to 12-year-old children of Slovenia (boys $18.3 \%$ and $6.5 \%$, girls $18.5 \%$ and $6.7 \%$ respectively).
There are some limitations of the study. After 1996 (when new education legislation was accepted) only healthy students wishing to participate and having the written consent of their parents are included in SLOFIT system. According to annual reports, slightly less than $95 \%$ of primary school boys and girls below the age of 15 were measured every year. Nevertheless, the sampling procedure was the same throughout the study. Therefore, there is no reason for the described trends not to apply to the entire population of Ljubljana.

Note also that as almost entire population of students were included, the confidence intervals as evaluated by Collett formula are actually narrower (more precise) than reported in the results of this study.

\section{CONCLUSION}

Enormous socio-political and economic changes in Slovenia in the last 20 years have strongly influenced the lifestyles, nutritional habits of children and youth and their physical development (37-41). Clearly, the prevalence of OW\&OB is also taking on epidemic proportions in Ljubljana's school population. Obesity is growing at higher rates than overweight, especially among boys. Obesity in childhood often follows into adulthood $(27,54)$, which further supports the importance of preventing childhood obesity. More efficient management of the ever-increasing problem of OW\&OB requires a comprehensive, multi- and inter-disciplinary approach as well as the establishment of a supportive environment that will encourage and ensure healthy conduct of children and youth. An efficient approach necessitates systemic measures from all competent authorities, a transformation of the health system into one supporting the prevention of illness and the cooperation of nutritional and other experts and media. Adequate education and the promotion of a healthy lifestyle needs to be included into formal and informal education, as the establishment of healthy decisionmaking patterns and a healthy lifestyle for all age groups is a prerequisite for alleviating the problem of OW\&OB (55). Therefore, certain measures are suggested such as public interventions focused on changing dietary intake and physical activity, safeguarding the school neighbourhood so that children can walk or cycle to and from school, maintenance of playgrounds near the school thus allowing for spontaneous physical activity, an improvement in the quality of PE, e.g. a smaller number of children per teacher in the first few years of education, involving the combined teaching of general teachers and PE teachers $(56,57)$, and free access to out-of school sport programmes for all children. However, it is also vital that parents ensure healthy eating habits and limit children's time spent in front of television and computer screens. 


\section{References}

1. Ferreira I, van der Horst K, Wendel-Vos W, Kremers S, van Lenthe FJ, Brug J. Environmental correlates of physical activity in youth: a review and update. Obes Rev 2007; 8: 129-54.

2. Hills AP, Andersen LB, Byrne NM. Physical activity and obesity in children. Br J Sports Med 2011; 45: 866-70.

3. Steinbeck KS. The importance of physical activity in the prevention of overweight and obesity in childhood: a review and an opinion. Obes Rev 2001; 2: 117-30.

4. Ogden CL, Carroll MD, Kit BK, Flegal KM. Prevalence of obesity and trends in body mass index among US children and adolescents, 1999-2010. JAMA 2012; 307: 483-90.

5. Wang $Y$, Lobstein T. Worldwide trends in childhood overweight and obesity. Int J Pediatr Obes 2006; 1: 11-25.

6. Wijnhoven TM, van Raaij JM, Spinelli A, Rito Al, Hovengen R, Kunesova M et al. WHO European Childhood Obesity Surveillance Initiative 2008: weight, height and body mass index in 6-9-year-old children. Pediatr Obes 2013; 8: 79-97.

7. Dehghan M, Akhtar-Danesh N, Merchant AT. Childhood obesity, prevalence and prevention. Nutr J 2005; 4: 24.

8. Stamatakis E, Primatesta P, Chinn S, Rona R, Falascheti E. Overweight and obesity trends from 1974 to 2003 in English children: what is the role of socioeconomic factors? Arch Dis Child 2005; 90: 999-1004.

9. Mokdad AH, Ford ES, Bowman BA, Dietz WH, Vinicor F, Bales VS et al. Prevalence of obesity, diabetes, and obesity-related health risk factors, 2001. JAMA 2003; 289: 76-9.

10. Reilly JJ. Descriptive epidemiology and health consequences of childhood obesity. Best Pract Res Clin Endocrinol Metab 2005; 19: 327-41.

11. Lobstein T, Baur L, Uauy R. Obesity in children and young people: a crisis in public health. Obes Rev 2004; 5(Suppl 1): 4-104.

12. Storch EA, Milsom VA, Debraganza N, Lewin AB, Geffken GR, Silverstein JH. Peer victimization, psychosocial adjustment, and physical activity in overweight and at-risk-for-overweight youth. J Pediatr Psychol 2007; 32: 80-9.

13. Starc G, Strel J. Is there a rationale for establishing Slovenian body mass index references of school-aged children and adolescents? Anthrop Notebooks 2011; 17: 89-100.

14. Haug E, Rasmussen M, Samdal O, lannotti R, Kelly C, Borraccino A et al. Overweight in school-aged children and its relationship with demographic and lifestyle factors: results from the WHO-Collaborative Health Behaviour in School-aged Children (HBSC) study. Int J Public Health 2009; 54(Suppl 2): 167-79.

15. Yngve A, De Bourdeaudhuij I, Wolf A, Grjibovski A, Brug J, Due $P$ et al. Differences in prevalence of overweight and stunting in 11-year olds across Europe: The Pro Children Study. Eur J Public Health 2008; 18: 126-30.

16. Currie C, Zanotti C, Morgan A, Currie D, de Looze M, Roberts C et al. Social determinants of health and well-being among young people. Health behaviour in school-aged children (HBSC) study: international report from the 2009/2010 survey. Copenhagen: WHO Regional Office for Europe, 2012.

17. Peckham CS, Stark O, Simonite $\mathrm{V}$, Wolff $\mathrm{OH}$. Prevalence of obesity in British children born in 1946 and 1958. Br Med J 1983; 286: 1237-42.

18. Whelton H, Harrington J, Crowley E, Kelleher V, Cronin M, Perry IJ. Prevalence of overweight and obesity on the island of Ireland: results from the North South Survey of Children's Height, Weight and Body Mass Index, 2002. BMC Public Health 2007; 7: 187.

19. Moreno L, Sarria A, Fleta J, Rodriguez G, Bueno M. Trends in obesity among children in Aragon (Spain) 1985 to 1995. Int J Obes Relat Metab Disord 1998; 19 : S7.

20. Holmback U, Fridman J, Gustafsson J, Proos L, Sundelin C, Forslund $A$. Overweight more prevalent among children than among adolescents. Acta Paediatr 2007; 96: 577-81.
21. Yuca SA, Yilmaz C, Cesur Y, Dogan M, Kaya A, Basaranoglu $M$. Prevalence of overweight and obesity in children and adolescents in eastern Turkey. J Clin Res Pediatr Endocrinol 2010; 2: 159-63.

22. Elmadfa I, Godina-Zarfl B, König J, Dichtl M, Faist V. Prevalence of overweight and plasma lipids in 7-18 year old Austrian children and adolescents. Int J Obes Relat Metab Disord 1993; 17: S35.

23. Maffeis C, Schutz Y, Piccoli R, Gonfiantini E, Pinelli L. Prevalence of obesity in children in north-east Italy. Int J Obes Relat Metab Disord 1993; 17: 287-94.

24. Vuorela N, Saha MT, Salo MK. Change in prevalence of overweight and obesity in Finnish children: comparison between 1974 and 2001. Acta Paediatr 2011; 100: 109-15.

25. Sweeting HN. Gendered dimensions of obesity in childhood and adolescence. Nutr J 2008; 7: 1.

26. Leskošek B, Strel J, Kovač M. Overweight and obesity in Slovenian schoolgirls, 1991-2006. Coll Antropol 2010; 34: 1303-8.

27. Starc G, Strel J. Tracking excess weight and obesity from childhood to young adulthood: a 12-year prospective cohort study in Slovenia. Public Health Nutr 2011; 14: 49-55.

28. Planinšec J, Fošnarič $S$. Body mass index and triceps skinfold thickness in prepubertal children in Slovenia. Coll Antropol 2009; 33: 341-5.

29. Avbelj M, Saje-Hribar N, Seher-Zupančič M, Brcar P, Kotnik P, Iršič A et al. Overweight and obesity prevalence among 5-yearold children and 15- to 16-year-old adolescents in Slovenia. Zdrav Vestn 2005; 74: 753-9.

30. Kovač M, Jurak G, Leskošek B. The prevalence of excess weight and obesity in Slovenian children and adolescents from 1991 to 2011. Anthrop Notebooks 2012; 18: 91-103.

31. Dietz WH. Health consequences of obesity in youth: childhood predictors of adult disease. Pediatrics 1998; 101: 518-25.

32. Singh AS, Mulder C, Twisk JW, van Mechelen W, Chinapaw MJ. Tracking of childhood overweight into adulthood: a systematic review of the literature. Obes Rev 2008; 9: 474-88.

33. Slovene Municipalities in Numbers. Statistical Office of Republic of Slovenia. Available May 5, 2013 at: http://www.stat.si/ ObcineVStevilkah/Vsebina. aspx?leto=2011\&id=82\&lang=eng.

34. Strel J, Ambrožič F, Kondrič M, Kovač M, Leskošek B, Štihec J et al. Sports Educational Chart. Ljubljana: Ministry of Education and Sport, 1997.

35. Cole TJ, Bellizzi MC, Flegal KM, Dietz WH. Establishing a standard definition for child overweight and obesity worldwide: international survey. BMJ 2000; 320: 1240-3.

36. Collett D. Modelling binary data. London: Chapman and Hall, 1991.

37. Pušnik M, Starc G. An entertaining (r)evolution: the rise of television in socialist Slovenia. Media Cult Soc 2008; 30: 777-93.

38. Kobe $\mathrm{H}$, Štimec M, Ribič $\mathrm{CH}$, Fidler Mis N. Food intake in Slovenian adolescents and adherence to the Optimized Mixed Diet: a nationally representative study. Public Health Nutr 2012; 15: 600-8.

39. Jurak G. Sporting lifestyle vs. 'cigarettes \& coffee' lifestyle of Slovenian high school students. Anthrop Notebooks 2006; 12 : 79-95.

40. Strel J, Kovač M, Jurak G. Physical and motor development, sport activities and lifestyles of Slovenian children and youth: changes in the last few decades In: Brettschneider WD, Naul $\mathrm{R}$, editors. Obesity in Europe: young people's physical activity and sedentary lifestyles. Frankfurt am Main: Peter Lang, 2007: 243-64.

41. Starc G, Strel J, Kovač M. Telesni in gibalni razvoj slovenskih otrok in mladine v številkah. Šolsko leto 2007/08. Ljubljana: Faculty of Sport, 2010.

42. Brener ND, McManus T, Galuska DA, Lowry R, Wechsler $\mathrm{H}$. Reliability and validity of self-reported height and weight among high school students. J Adolesc Health 2003; 32: 281-7. 
43. Ferreira RJ, Marques-Vidal PM. Prevalence and determinants of obesity in children in public schools of Sintra, Portugal. Obesity (Silver Spring) 2008; 16: 497-500.

44. Sjoberg A, Lissner L, Albertsson-Wikland K, Marild S. Recent anthropometric trends among Swedish school children: evidence for decreasing prevalence of overweight in girls. Acta Paediatr 2008; 97: 118-23.

45. Yearly sport program of the Municipality of Ljubljana. Available Mar 15, 2013 at: www.ljubljana.si/si/mol/mestna-uprava/oddelki/ sport/.

46. Stamatakis E, Wardle J, Cole TJ. Childhood obesity and overweight prevalence trends in England: evidence for growing socioeconomic disparities. Int J Obes 2010; 34: 41-7.

47. Cattaneo A, Monasta L, Stamatakis E, Lioret S, Castetbon K, Frenken $\mathrm{F}$ et al. Overweight and obesity in infants and preschool children in the European Union: a review of existing data. Obes Rev 2010; 11: 389-98.

48. Eriksson M, Rasmussen F, Nordqvist T. Changes in shape and location of BMI distributions of Swedish children. Acta Paediatr 2005; 94: 1558-65.

49. Daniels SR, Khoury PR, Morrison JA. The utility of body mass index as a measure of body fatness in children and adolescents: differences by race and gender. Pediatrics 1997; 99: 804-7.
50. Shephard RJ. The obesity epidemic: a challenge to pediatric work physiologists. Pediatric Exercise Sci 2005; 17: 3-17.

51. Rolland-Cachera MF, Cole TJ, Sempe M, Tichet J, Rossignol C, Charraud A. Body Mass Index variations: centiles from birth to 87 years. Eur J Clin Nutr 1991; 45: 13-21.

52 . Krieger N. Genders, sexes, and health: what are the connectionsand why does it matter? Int J Epidemiol 2003; 32: 652-7.

53. Škerlj B. Splošna antropologija v osnovnih potezah. Ljubljana: Državna založba Slovenije, 1948.

54. Whitaker RC, Wright JA, Pepe MS, Seidel KD, Dietz WH. Predicting obesity in young adulthood from childhood and parental obesity. N Engl J Med 1997; 337: 869-73.

55. Artnik B, Bajt M, Bilban M, Borovničar A, Brguljan J, Djomba JK et al. Zdravje in vedenjski slog prebivalcev Slovenije: trendi v raziskavah CINDI 2001-2004-2008. Ljubljana: Inštitut za varovanje zdravja Republike Slovenije, 2012.

56. Jurak G, Kovač M, Strel J. Influence of the enhanced physical education curriculum on the physical fitness of children. Croat J Edu 2012; 13: 41-70.

57. Starc G, Strel J. Influence of the quality implementation of a physical education curriculum on the physical development and physical fitness of children. BMC Public Health 2012; 12: 61 . 